\title{
The Application of Rhizobacteria and Indigenous Microorganism on Cow Rumen in Soybean Plants (Glycine max L.)
}

\author{
Meli Astriani \\ Department of Biology, Faculty of Mathematics and Natural \\ Sciences \\ Universitas Negeri Malang. \\ Malang, Indonesia
}

Abdul Latief Abadi

Department of Plant Pest and Diseases, Faculty of Agriculture Brawijaya University, Jl. Veteran 65145

Malang, Jawa Indonesia

\begin{abstract}
Soybeans are national food crop commodity with a high level of consumption per year. Efforts to increase soybean production are accomplished through fertilizer application. The utilization of chemical fertilizers, however, can negatively impact the environment. One alternative to the application of fertilizer is to provide superior microbes that are beneficial to the plants. This study aimed to determine how the application of rhizobacteria and indigenous microorganism in cow rumen affects the growth of soybean plants. This study method included isolate reculture, identification, and selection for soybean plant application using one factor of a completely randomized design method consisting of five treatment levels. The results indicated that the superior isolates, $\mathrm{AJ8}$, had the highest potential utilization as Indole Acetic Acid hormone producer, while MTA1 isolates were phosphate solvent isolates. The identification results using Microbact showed that AJ8 isolates had $99 \%$ similarity with Acinetobacter baumanii, while MTA1 isolates were identified as Propionibacterium granulosum. Application of Acinetobacter baumanii AJ8 and Propionibacterium granulosum MTA1 bacteria in single treatment has more potential to increase the plant height and root length compared to consortium treatment. The potential use of the superior bacteria discovered still needs further study until the biological fertilizer formulations formed can reduce the utilization of chemical fertilizers.
\end{abstract}

Keywords-soybean, indigenous microorganism, biological fertilizer, Acinetobacter baumanii, Propiniobacterium granulosum

\section{INTRODUCTION}

Soybean is a national food crop commodity with the highest level of consumption per year (Ministry of Agriculture Strategic Plans 2015-2019). The inability of a local soybean crop to fulfill the food needs causes the government to conduct soybean import. High soybean demand is imbalanced with soybean slow-growing production. Efforts have been made to elevate the soybean production in Indonesia, one of which is by land improvement with a fertilizing system [1].

Fertilization aims to complete nitrogen, phosphate, potassium nutrient element for crops [2]. However, the

\author{
Siti Zubaidah \\ Department of Biology, Faculty of Mathematics and Natural \\ Sciences \\ Universitas Negeri Malang. \\ Malang, Indonesia \\ siti.zubaidah.fmipa@um.ac.id
Endang Suarsini
Department of Biology, Faculty of Mathematics and Natural Sciences
Universitas Negeri Malang.
Malang, Indonesia

administration of chemical fertilizer is inefficient as not all fertilizer administered can be absorbed by crops. Besides, chemical fertilizer will have an impact on soil fertility declination, leaving harmful substance residue in the environment [3] [4] [5]. Technological innovation role in increasing crop productivity should be necessary existed. One alternative way to conduct this is by the utilization of growth hormone-producing microbes and nutrient provider microbes, such as nitrogen and phosphate as the raw material of biological fertilizer production.

Biological fertilizer is a fertilizer that contains living microorganisms to improve nutrients needed, facilitate organic elements in the soil, and increase the plant growth [6]. Biofertilizer has a high potential as an alternative of chemical fertilizers, as it is more environmentally friendly, easy to apply, non-toxic, and more effective application [7], besides contributing to the production cost reduction [8]. Some superior microbes that have been extensively studied and developed as a biological agent to enhance crop growth are rhizobacteria.

Rhizobacteria is a living microorganism in plant root known as Plant Growth Promotion Rhizobacteria (PGPR) [9]. Some rhizobacteria such as Agrobacterium tumefaciens, Agrobacterium rhizogenes, Erwinia herbicola, Rhizobium, Alcaligenes faecalis, Enterobacter cloacae, Acetobacter diazotrophicus, and Bradyrhizobium japonicum produce a substance of plant growth booster, such as Indole Acetic Acid (IAA) [10]. IAA hormone is a physiological group of phytohormones that play an important role in plant growth [11] [12] [13]. Approximately $80 \%$ of bacteria that colonize the rhizosphere have the ability to synthesize IAA because the root exudate secretes tryptophan. tryptophan compounds are inducers for IAA biosynthetic pathways in bacteria [14]. Biotechnological developments have emerged environmentally friendly alternative products such as compound microbial products to enhance plant growth. The development of inoculant product has been widely applied as biological fertilizer derived from Rhizobacteria, i.e., 
Bradyrhizobium japonicum, Bacillus subtilis, Pseudomonas corrugata, Bulkhoderia, Serratia marcescens [15] [16] [17] [18].

PGPR treatment to the environment can improve soil physical, chemical, and biological properties. In addition to rhizobacteria, liquid fertilizer from the fermented beef rumen, namely Indigenous Micro-Organism (IMO) of cow rumen have been widely applied in the field experiment and been able to increase crop growth. IMO contains natural microbes that can adapt to any environmental conditions. Content of organic material from IMO cow rumen can improve soil fertility [19]. Ruminant digestion contains microbes that have phytase enzyme that can decompose phytate into inorganic orthophosphate and simple phosphoric group like monophosphate. Also, cow rumen is known to be profitable in agriculture as possessing high cellulose [20], chitinase [21], and methane monooxygenase [22] enzyme activity. The effectiveness of rhizobacteria and indigenous rumen cow needs to be observed further in the form of separate and mixture culture against crop growth. The purpose of this study was to testify the ability of rhizobacteria superior isolates and indigenous rumen cow in single and consortium on the soybean crops. This study is expected to contribute to the development of bio-inoculant of biological fertilizer, which is more effective in increasing soybean production.

\section{METHOD}

\section{A. Place and Period}

This study was conducted on January-April, 2019 in Microbiology and Greenhouse Laboratory, Department of Biology, Universitas Negeri Malang, Indonesia.

\section{B. Isolate Reculture}

Two isolates used in this study were AJ8 as Indole Acetic Acid (IAA) hormone-producing rhizobacteria and MTA1 from cow rumen as phosphate solvent bacteria. Isolate reculture was done by inoculating AJ8 and MTA1 isolate on Nutrient Agar (NA) media as the culture assay using quadrant streak plate method. Two isolates were confirmed based on the morphological characteristics using Gram staining method. The pure isolate was then streaked on the slant agar as culture stock.

\section{Bacterial Identification}

Bacterial identification was made using Sistem Oxiod ${ }^{T M}$ Microbact GNB 24E (Thermo-Fisher Scientific, Waltham, Massachusetts, USA). Bacterial isolates used for physiological assay were rejuvenated on slant Nutrient Agar in 24 hours. The culture was suspended into the physiological salt solution and homogenized using vortex. $0.1 \mathrm{~mL}$ of the solution was added into each well of $12 \mathrm{~A}$ and $12 \mathrm{~B}$ kit, then incubated for 24 hours at $37^{\circ} \mathrm{C}$ [23]. Assay profile result was matched using Microbact 2000 software to obtain bacterial species identification result.

\section{Bacterial Culture Effectiveness Assay on Soybean Crop in The Greenhouse}

- Crop preparation

Anjasmoro variety soybean seeds were obtained from Balai Penelitian Tanaman Kacang dan Umbi (Balitkabi), Malang. Soybean seeds were soaked and washed using sterile aqua dest, then planted on $2 \mathrm{~cm}$ depth in the polybag. Planting media used soil which had been sterilized using autoclave at $121^{\circ} \mathrm{C}$ in 1 atm pressure.

- Bacterial culture preparation

One loop of 24-hour bacterial isolates were inoculated in 50 $\mathrm{mL}$ of Nutrient Broth medium and incubated for 24 hours. The culture was given $10 \mathrm{~mL}$, with the total bacterial cell of $10^{8} \mathrm{cell} / \mathrm{mL}$ around the plant roots.

- Study design

This study was arranged using a Completely Randomized Design with six treatments and four replications. Each treatment administration is explained in Table 1.

TABLE I. EFFECTIVENESS ASSAY BIOLOGICAL

\begin{tabular}{|l|l|l|c|}
\hline No & Code & Treatment & Replication \\
\hline 1 & P1 & $\begin{array}{l}\text { A negative control without } \\
\text { bacterial inoculation }\end{array}$ & 4 \\
\hline 2 & P2 & $\begin{array}{l}\text { Positive control with NPK } \\
\text { fertilizer }\end{array}$ & 4 \\
\hline 3 & P3 & $\begin{array}{l}\text { AJ8 bacteria culture } \\
\text { administration }\end{array}$ & 4 \\
\hline 4 & P4 bacteria culture & 4 \\
\hline 5 & P5 & $\begin{array}{l}\text { MTA1 AJ8 + MTA1 } \\
\text { Total unit assay }\end{array}$ \\
\hline
\end{tabular}

\section{- Data Analysis}

Crops were observed for 14 days after planting based on the root length, plant height, lateral root number, and wet weight. Plant height was measured from the soil surface until the highest tip of leaves, root length was measured from the base root until the tap root end, lateral root number was calculated based on the root branches, and wet weight was measured using a digital scale. Data obtained was analyzed using ANOVA with SPSS 21.0 software and compared using Duncan test on 5\% significant range [24].

\section{RESULT AND DISCUSSION}

\section{A. Isolate Reculture}

AJ8 and MTA1 isolate grew after incubated for 24 hours on NA media. AJ8 and MTA1 isolate characteristics are listed in Table 2.

TABLE II.

ISOLATE MORPHOLOGICAL CHARACTERISTICS

\begin{tabular}{|l|l|l|l|l|c|l|l|}
\hline \multirow{2}{*}{$\begin{array}{l}\text { Isolate } \\
\text { Code }\end{array}$} & Shape & Color & Edge & Elevation & $\begin{array}{l}\text { Colony } \\
\text { diameter }\end{array}$ & $\begin{array}{l}\text { P } \\
\text { Solvent } \\
\text { Index } \\
\text { (mm) }\end{array}$ & $\begin{array}{l}\text { IAA } \\
\text { (ppm) }\end{array}$ \\
\hline AJ8 & Rounded & Cream & Flat & Concave & 1.11 & - & 38.39 \\
\hline MTA1 & Rounded & White & Flat & Concave & 0.39 & 7.66 & - \\
\hline
\end{tabular}

This study used two isolates chosen from the previous study, i.e., AJ8 and MTA1. AJ8 isolate had Indole Acetic Acid (IAA) hormone production ability with $38.39 \mathrm{ppm}$, while MTA1 was able to dissolve phosphate with the solvent index of $7.66 \mathrm{~mm}$ [25]. Based on the Gram staining result, AJ8 isolate had rounded shape, flat edge, concave elevation, and cream colony. Microscopical observation of Gram staining result indicated that AJ8 was included as coccobacillus Gram-negative bacteria (Figure 1a,b). MTA1 isolate morphologically had rounded shape, flat edge, concave elevation, cream color. MTA1 isolate was also included as basil Gram-positive bacteria (Figure 1c,d). 

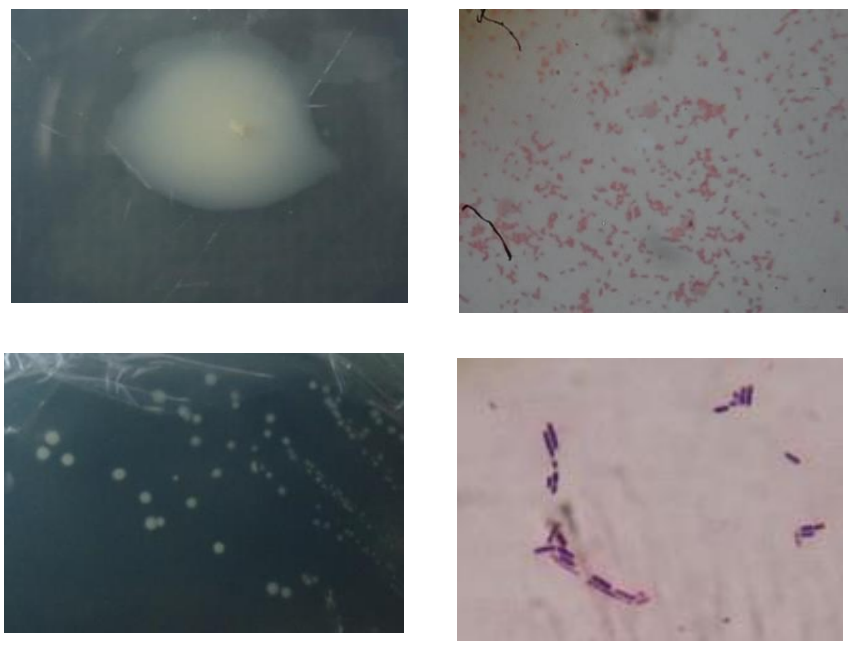

(c)

(d)

Fig. 1. Morphological characteristics and staining result with 1000x magnification; (a) AJ8 colony morphology, (b) AJ8 microscopic cell, (c) MTA1 colony morphology, (d) MTA1 microscopic cell

\section{B. Bacterial Identification using Microbact}

AJ8 isolate identification using Microbact had positive test results of motility, lysin, glucose, xylose, citrate, and catalase (Table 3). The profile of test results showed that AJ8 isolate had $99 \%$ similarity rate with Acinetobacter baumanii.

TABLE III. IDENTIFICATION BACTERIA USING MicRobaCT

\begin{tabular}{|c|c|c|c|c|c|c|c|}
\hline \multirow[t]{2}{*}{ No } & \multirow{2}{*}{$\begin{array}{l}\text { Biochemical } \\
\text { Test }\end{array}$} & \multicolumn{2}{|c|}{ Results } & \multirow[t]{2}{*}{ No } & \multirow{2}{*}{$\begin{array}{l}\text { Biochemical } \\
\text { Test }\end{array}$} & \multicolumn{2}{|c|}{ Results } \\
\hline & & AJ8 & MTA1 & & & AJ8 & MTA1 \\
\hline 1 & Spore & - & - & 18 & Malonate & - & - \\
\hline 2 & Oksidase & - & - & 19 & Inositol & - & - \\
\hline 3 & Motility & + & + & 20 & Rhamnose & - & - \\
\hline 4 & Nitrate & - & + & 21 & Sucrose & - & + \\
\hline 5 & Lysine & + & - & 22 & Lactose & - & - \\
\hline 6 & Ornithine & - & - & 23 & Arabinose & - & - \\
\hline 7 & $\mathrm{H}_{2} \mathrm{~S}$ & - & - & 24 & Adonitol & - & - \\
\hline 8 & Glukose & + & + & 25 & Raffinosa & - & - \\
\hline 9 & Manitol & - & - & 26 & Salicin & - & - \\
\hline 10 & Xylosa & + & - & 27 & Arginin & - & - \\
\hline 11 & ONPG & - & + & 28 & catalase & + & + \\
\hline 12 & Indole & - & - & 29 & coagulase & - & - \\
\hline 13 & Urease & - & - & 30 & hemolysis & - & - \\
\hline 14 & V-P & - & - & 31 & $\begin{array}{l}\text { Novobiosin } \\
\text { sensitive test }\end{array}$ & - & - \\
\hline 15 & Sitrate & + & - & 32 & $\begin{array}{l}\text { Starch } \\
\text { hydrolysis }\end{array}$ & - & - \\
\hline 16 & TDA & - & - & 33 & $\begin{array}{l}\text { Casein } \\
\text { hydrolysis }\end{array}$ & - & - \\
\hline 17 & Gelatin & - & - & & & & \\
\hline
\end{tabular}

+ : for positive; - : negative results

A. baumanii is widely reported as having the ability to produce Indole-acetic acid (IAA) hormone by involving IPDC gene through Indole-3-Pyruvic Acid (IpyA) pathway. The role of IAA hormone produced by $A$. baumanii biologically increases microbial interactions with plants, as well as enhancing the crop growth. Some strains of Acinetobacter genus are known to be involved in plant growth stimulation. Other strains of Acinetobacter show as the plant growth promotion Rhizobacteria (PGPR) [26] [27].
Acinetobacter sp. has a high ability to produce IAA during fermentation with $62.428 \mathrm{ppm}$ [28]. Recent studies reported that $A$. baumanii also controlled IAC gene repression to degrade IAA that allegedly hydrolyzed IAA into two hydroxy-indole-3-acetic acids in subsequent dioxindole-3acetic acid to the final catechol product. IAA is used as a single carbon source and energy for bacteria [29]. In addition, Acinetobacter genus also has the ability to improve the availability of nitrogen elements [30], dissolve mineral phosphate [31], produce siderophore, and assist waste remediation [27]. Acinetobacter strain RSC7 is also used as a biofertilizer formulation for Vigna plant growth promotor at the seed stage [32].

The positive MTA1 isolation test results using Microbact indicated that isolate was identified as Propionibacterium granulosum. P. granulosum is motile bacteria with the capability of degrading nitrate, glucose, and sucrose, besides producing catalase and synthesizing propionic acid using transcarboxylase enzyme in the fermentation process. Propionibacterium is Actinobacteria phylum found everywhere and utilized as a potential biological fertilizer to increase plant growth. Some of Propionibacterium capabilities reported are phosphorus and potassium solvent, and nitrogen fixation [33]. Propionibacteria are also involved in nitrogen element fixation at legume crops under symbiotic conditions and free-living [34]. P. granulosum MTA1 has the ability to dissolve the highest phosphate content either in solid or liquid medium as mentioned in the previous study, contributing the sustainable farming. Bacterial phosphate solvent is considered important in the agricultural field due to the ability to enhance crop growth, decompose organic matter, increase plant nutrient cycle, and reduce chemical fertilizer utilization [35].

\section{Bacterial Application on Soybean Crop}

AJ8 and MTA1 isolate assay as soybean sprout growth agent was done by inoculating the isolates into Anjasmoro variety soybean sprouts. Soybean sprout growth was observed for 14 days. The analysis results of root length and plant height indicated a significant influence of AJ8 (P3) and MTA1 (P4) isolate treatment. Single bacterial culture treatment can increase the plant height by $20-25 \%$ (table 3 ), while the combination of AJ8 + MTA1 isolate (P5) had a significant effect on the plant height by $15 \%$ compared to the negative control (Table 4).

TABLE IV. EFFECT OF AJ8 AND MTA1 BACTERIAL TREATMENT IN SOYBEAN

\begin{tabular}{|c|c|c|c|c|}
\hline Treatment & $\begin{array}{c}\text { Plant } \\
\text { height } \\
(\mathbf{c m})\end{array}$ & $\begin{array}{c}\text { Primer } \\
\text { roots } \\
\text { length } \\
(\mathbf{c m})\end{array}$ & $\begin{array}{c}\text { Number of } \\
\text { lateral roots }\end{array}$ & $\begin{array}{c}\text { Wet } \\
\text { weigh } \\
\mathbf{t}(\mathbf{g})\end{array}$ \\
\hline K- (P1) & $37.83^{\mathrm{a}}$ & $5.33^{\mathrm{a}}$ & $22.00^{\mathrm{a}}$ & $1.74^{\mathrm{a}}$ \\
\hline $\mathrm{K}+(\mathrm{P} 2)$ & $40.66^{\mathrm{ab}}$ & $7.60^{\mathrm{ab}}$ & $23.66^{\mathrm{a}}$ & $1.89^{\mathrm{a}}$ \\
\hline AJ8 (P3) & $45.93^{\mathrm{b}}$ & $10.66^{\mathrm{b}}$ & $23.66^{\mathrm{a}}$ & $2.18^{\mathrm{a}}$ \\
\hline MTA1 (P4) & $45.23^{\mathrm{b}}$ & $10.10^{\mathrm{ab}}$ & $22.33^{\mathrm{a}}$ & $1.88^{\mathrm{a}}$ \\
\hline $\begin{array}{c}\text { AJ8 + MTA1 } \\
(\mathrm{P} 5)\end{array}$ & $42.56^{\mathrm{ab}}$ & $5.50^{\mathrm{a}}$ & $23.66^{\mathrm{a}}$ & $1.86^{\mathrm{a}}$ \\
\hline
\end{tabular}

The number followed by different letters in the column showed significantly different results based on the Duncan test at $\alpha=0.05$ 
A. baumanii AJ8 treatment (P3) was able to give a significant effect on the root length; however, it had no significant effect on the lateral root number. This was suspected that IAA hormone produced by bacteria only affected the root length. Exogenous generated IAA hormone affects the lateral and adventitious root growth [10]. IAA-induced roots with high range administration between $\left[10^{-4}-10^{-6}\right] \mathrm{M}$ will inhibit the primary root length and form the root hair, while primary root growth is stimulated with low IAA administration, i.e. $\left[10^{-9}-10^{-12}\right] \mathrm{M}$.

The consortium treatment of $A$. baumanii AJ8 and $P$. granulosum MTA1 (P5) did not affect the root length, lateral root number, and plant wet weight. Consortium treatment was unlike the single culture with a significant effect on the plant height and primary root length. The consortium bacterial treatment in one culture did not necessarily have a significant influence on plant growth because bacteria produce metabolite compound suspected to inhibit other bacteria activity. Thus A. baumanii AJ8 and $P$. granulosum MTA1 bacteria will be more efficiently utilized in a single treatment to enhance the plant growth. This study is the preliminary part limited to the bacterial identification and applications in plants. It is necessary to confirm the bacterial molecular identification, and further studies are needed to discover IAA hormone-producing bacteria and phosphate solvent activity in crops until reaching the seed production phase.

\section{CONCLUSION}

The identification result using Microbact ${ }^{\mathrm{TM}}$ 24E indicated AJ8 isolate had 99\% similarity with Acinetobacter baumanii AJ8 and MTA1 isolate was identified as Propionibacterium granulosum. A. baumanii AJ8 and P. granulosum MTA1 in the single treatment had a more potential increase in plant height and primary root length compared to consortium treatment. Further studies are necessary for molecular bacterial identification and application on the crop until reaching the production phase.

\section{ACKNOWLEDGMENT}

Authors would like to thank DPRM DIKTI for funding this study as presented on Doctoral Dissertation Research scheme under the contact number: 19.3.8/UN32.14/LT/2019.

\section{REFERENCES}

[1] P. K. Ghost, M. C. Manna, K. K. Bandyopadhyay, A. K. Ajay Tripathi, R. H. Wanjari, K. M. Hati, A. K. Misra, C. L. Acharya, and A. S. Rao, "Interspecific Interaction and Nutrient Use in Soybean/Sorghum Intercropping System,“ Am. Soc. of Agron., vol. 98, pp. 1097-1108, 2006.

[2] M. M. Alley and B. Vanlauwe, "The Role of Fertilizers in Integrated Plant Nutrient Management International Fertilizer,' Industry: France, 2009.

[3] K. K. Bandyopadhyay, A. K. Misra, P. K. Ghosh and K. M. Hati, "Effect of integrated use of farmyard manure and chemical fertilizers on soil physical properties and productivity of soybean," Soil and Tillage Res., vol. 110, no. 21, pp. 115-125, 2010.

[4] U. Sharma, S. S. Paliyal, S. P. Sharma and G. D. Sharma, "Effects of Continuous Use of Chemical Fertilizers and Manure on Soil Fertility and Productivity of Maize-Wheat under Rainfed Conditions of the Western Himalayas," Commun. Soil Sci. Plant Anal., vol. 45, no. 20, pp. 2647-2659, 2014.
[5] D. Geisseler and K. M. Scow, "Long-term effect of mineral fertilizers on soil microorganisms," Soil Bio. and Biochem., vol. 75, pp. 54-63. 2014.

[6] J. K. Vessey, "Plant growth-promoting rhizobacteria as biofertilizers," Plant and Soil, vol. 255, pp. 571-586, 2003.

[7] M. Mazid and T. A Khan, "Future of Bio-fertilizers in Indian Agriculture: An Overview," Inter. J. Agric. Food Res., vol. 3, no. 3, pp. 10-23. 2014.

[8] M. M. S. Tahir, S. Mirza, M. R Hameed, Dimitrov, and H Smidt, "Cultivation-Based and Molecular Assessment of Bacterial Diversity in the Rhizosheath of Wheat under Different Crop Rotations," Plos One, vol. 10, no. 6. pp. 1-28. 2015.

[9] B. Lugtenberg and F. Kamilova F, "Plant-Growth-Promoting Rhizobacteria,” Annu. Rev. Microbiol., vol. 63, pp. 541-556. 2009.

[10] C. L. Patten and B. R. Glick, "Role of Pseudomonas putida Indole acetic Acid in Development of the Host Plant Root System," Appl. Environ. Microbiol., vol. 68, no. 8. pp. 3795-3801. 2002.

[11] O. Apine and J. P. Jadhav, "Optimization of medium for indole-3acetic acid production using Pantoea agglomerans strain PVM," J. Appl. Microbiol., vol. 110, pp. 1235-1244. 2011.

[12] D. Vishwakarma, J. K. Thakur and S. C. Gupta, "Study of production of indole acetic acid by soil and plant bacterial isolates on different media,” Inter. J. Chem. Stud., vol. 5, no. 6, pp. 639-641. 2017.

[13] P. Jatav, A. Gupta, S. S. Ahirwar, S. Jatav, A. Jatav, K Kushwaha, "Production of Plant Growth Hormones Indole-3-Acetic Acid (IAA) Using Bacillus by Batch Fermentation Global,' J. Bio-Sci. Biotechnol., vol. 6, no. 4. pp. 612-616. 2017.

[14] S. Spaepen and J. Vanderleyden, "Auxin and Plant-Microbe Interactions," Cold Spring Harbor Laboratory Press. 2011.

[15] J. Ulzen, R. C. Abaidoo, N. E. Mensah, C. Masso and A. AbdelGadir, "Bradyrhizobium Inoculants Enhance Grain Yield of Soybean and Cowpea in Northern Ghana," Front. in Plant Sci., vol. 7, no. 1770, pp. 1-9. 2016

[16] P. Trivedi, A Pandey and L. M. S. Palni, "Carrier-based preparations of plant growth-promoting bacterial inoculants suitable for use in cooler regions". World J. Microbiol. Biotechnol., vol. 21, pp. 941-945. 2005 .

[17] N. R. Mubarik, I. Mahagiani and A. T. Wahyudi, "Production of IAA by Bradyrhizobium sp". Inter. J. Biol. Biomol. Agric. Food Biotechnol. Eng., vol, 7, no. 2, pp. 102-105. 2013.

[18] M. Astriani, N. R. Mubarik and . A. Tjahjoleksono, "Selection of bacteria producing indole-3-Acetic acid and its application on oil palm seedlings (Elaeis guineensis Jacq.)," Malays. J. Microbiol., vol. 12, no. 2, pp. 147-154, 2016.

[19] B. L. Kumar and D. V. R. S. Gopal. "Effective role of indigenous microorganisms for a sustainable environment," Biotech, vol. 5, pp. 867-876. 2015

[20] W. N. Sari, D. Safika and Y. Fahrimal. "Isolation and identification of a cellulolytic Enterobacter from rumen of Aceh cattle," Vet World, vol. 10, no. 12 , pp. 1515-1520. 2017.

[21] A. Ajayi, E. A. Onibokun, F. O. George and O. M. Atolagbe, "Isolation and Characterization of Chitinolytic Bacteria for Chitinase Production from the African Catfish Clarias gariepinus, ” Res. J. Microbiol., vol. 11, no. 4, pp. 119-125. 2016.

[22] L. Zhao, Q. Meng, Y. Li, H. Wu, Y. Huo and Xin, "Nitrate decreases ruminal methane production with slight changes to ruminal methanogen composition of nitrate-adapted steers," BMC Microbiol., vol. 18 , no. 2 , pp. $2-8,2018$

[23] S. Mailafia, O. H. Olabode, G. Okoh, C. Jacobs, S. G. Adamu, S. A and Onyilokwu, "Microbact $\mathrm{TM}^{\mathrm{TM}} 24 \mathrm{E}$ system identification and antimicrobial sensitivity pattern of bacterial flora from raw milk of apparently healthy lactating cows in Gwagwalada," Niger. J. Coast. Life Med., vol. 5, no. 8, pp. 356-359. 2017.

[24] P. Sivasakthivelan and P. Saranraj, "Azospirillum and its formulations: a review,” Int. J. Microbiol. Res., vol. 4, no. 3, pp. 275-275-287. 2013

[25] M. Astriani, S. Zubaidah, A. L. Abadi and E. Suarsini, "Isolation Bacterial Production Indole Acetic Acid (IAA) and Solubilizing Phosphate Indigenous Microorganism (MOL) of Rumen," Malays. J. Microbiol., in press.

[26] R. Zamin, D. Farokh Sachdev, N. K. Pour, A. Engineer, K. R. Pardesi S. Zinjarde, P. K. Dhakephalkar and B. Chopade, "Characterization of plant-growth traits of Acinetobacter species isolated from rhizosphere 
of Pennisetum glaucum,” J. Microbiol. Biotecnol., vol. 21, no. 6, pp. 556-566. 2011.

[27] H. R. Lin, H. Y. Shu and G. H. Lin, "Biological roles of indole-3-acetic acid in Acinetobacter baumannii," Microbiol. Res., vol. 216, pp. 3039. 2018.

[28] S. Antonius, R Budisatria, T. K and Dewi, "The use of Sprout as Precursor for the Production of Indole Acetic Acid by Selected Plant Growth Promoting Rhizobacteria Grown in the Fermentor," Microbiol. Indones., vol. 10, no. 4, pp. 131-138. 2016.

[29] R. Donoso, P. L. Novoa, A. Zúñiga, T. Timmermann, G. R. Gajardo and B Gonzáleza, "Biochemical and Genetic Bases of Indole-3-Acetic Acid (Auxin Phytohormone) Degradation by the Plant-GrowthPromoting Rhizobacterium Paraburkholderia phytofirmans PsJN," Appl. Environ. Microbiol., vol. 83, no. 1, pp. 1-20. 2017.

[30] D. Fitriyanti, N. R. Mubarik and A. Tjahjoleksono, "Characterization of phosphate solubilizing bacteria and nitrogen fixing bacteria from limestone mining region," Malays. J. Microbiol., vol. 13, no. 3, pp. 147-155, 2017

[31] A. Peix, E. Lang, S. Verbarg, C. Spröer, R. Rivas, I. S. Regina, P. F. Mateos, E. Martínez-Molina E, C. R. Barrueco and E.
EncarnaVelázquez, "Acinetobacter strains IH9 and OCI1 two rhizospheric phosphate solubilizing isolates able to promote plant growth, constitute a new genomovar of Acinetobacter calcoaceticus," Syst. Appl. Microbiol., vol. 32, no 5, pp. 334-341. 2009.

[32] P. Patel, R. Shah and K. Modi, "Isolation and Characterization of Plant Growth promoting potential of Acinetobacter sp. RSC71 Isolated from Saccharum officinarum cultivar Co 671, J. Exp. Biol. Agric. Sci., vol. 5, no. 4, pp. $2320-8694,2017$.

[33] N. Yadav and A. N. Yadav, "Actinobacteria for Sustainable Agriculture," J. Appl. Biotechnol. \& Bioeng., vol. 6, no. 1, pp. 38-41. 2019.

[34] A. Sathya, R. Vijayabharathi and S Gopalakrishman, "Characteristics of $P$. granulosum has the ability to motility, positively overhauling the nitrate, glucose, sucrose, and catalase forms, and has the ability to synthesize propionic acid by using the transcarboxylase enzyme in the fermentation process," Biotech., vol. 7, no. 102, pp. 1-10. 2017.

[35] F. Wu, J. Li, Y. Chen, L. Zhang, Y. Zhang, S. Wang, X. Shi, L Li and J. Liang. "Effects of Phosphate Solubilizing Bacteria on the Growth, Photosynthesis, and Nutrient Uptake of Camellia oleifera," Abel For., vol. 10 , no. 348 , pp. 1-10. 2019. 